\title{
PENGARUH TINGKAT PENDAPATAN DAN PENGETAHUAN EKONOMI TERHADAP TINGKAT KONSUMSI MAHASISWA PROGRAM PASCASARJANA UNIVERSITAS NEGERI SURABAYA
}

\author{
Entika Indrianawati, Pascasarjana Universitas Negeri Surabaya \\ nt1k4_cntk@yahoo.com \\ Yoyok Soesatyo, Universitas Negeri Surabaya \\ yoyoksoesatyo3@gmail.com
}

\begin{abstract}
ABSTRAK
Penelitian ini bertujuan untuk 1.) menganalisis pengaruh tingkat pendapatan terhadap tingkat konsumsi mahasiswa Program Pascasarjana Universitas Negeri Surabaya, 2.) menganalisis pengaruh pengetahuan ekonomi terhadap tingkat konsumsi mahasiswa Program Pascasarjana Universitas Negeri Surabaya, 3.) menganalisis pengaruh tingkat pendapatan dan pengetahuan ekonomi terhadap tingkat konsumsi mahasiswa Program Pascasarjana Universitas Negeri Surabaya. Populasi dalam penelitian ini adalah mahasiswa Program Pascasarjana Universitas Negeri Surabaya, dengan menggunakan teknik sampling propotional random sampling. Metode analisis menggunakan analisis regresi berganda. Hasil penelitian menunjukkan bahwa: 1.) tingkat pendapatan berpengaruh signifikan terhadap tingkat konsumsi mahasiswa Program Pascasarjana Universitas Surabaya, 2.) Pengetahuan ekonomi berpengaruh negatif dan signifikan terhadap tingkat konsumsi mahasiswa Program Pascasarjana Universitas Surabaya, 3.) Secara simultan tingkat pendapatan dan pengetahuan ekonomi mempunyai pengaruh nyata terhadap tingkat konsumsi mahasiswa Program Pascasarjana Universitas Surabaya.
\end{abstract}

Kata kunci: Tingkat Pendapatan, Pengetahuan Ekonomi, Tingkat Konsumsi

\section{ABSTRACT}

The study aims to 1.) analyzing the Influence of the Income Level to Consumption Level In Post Graduate Students Universitas Negeri Surabaya, 2.) analyzing the Influence of the Economics Knowledge to Consumption Level In Post Graduate Students Universitas Negeri Surabaya, 3.) analyzing the Influence of the Income Level and the Economics Knowledge of Consumption Level In Post Graduate Students Universitas Negeri Surabaya. The population in this study were Post Graduate Students Universitas Negeri Surabaya, using proportional random sampling technique sampling. Methods of analysis using multiple regression analysis. The results showed that the level of income has partially significant effect on the level of student consumption Post Graduate Students Universitas Negeri Surabaya. Economics Knowledge negatively affect consumption levels Post Graduate Students Universitas Negeri Surabaya. Income levels and economic knowledge simultaneously have a significant effect on the level of student consumption Post Graduate Students Universitas Negeri Surabaya.

Keyword: Income Level, Economics Knowledge, and Consumption Level 


\section{PENDAHULUAN}

Pengeluaran konsumsi masyarakat merupakan salah satu variabel makroekonomi. Setiap masyarakat tidak terlepas dari kegiatan konsumsi yang dilakukan guna untuk memperoleh kepuasan atas penggunaan barang dan jasa serta mencapai tingkat kemakmuran. Raharja dan Manurung (2008) dalam bukunya menuliskan teori konsumsi Keynes, menyebutkan bahwa konsumsi yang dilakukan saat ini tergantung dari pendapatan yang siap dibelanjakan saat ini (disposible income). Dengan demikian semakin besar pendapatan, maka semakin besar pula pengeluaran konsumsi.

Menurut Rachman (2001), pola konsumsi dan pengeluaran rumah tangga umumnya berbeda antara agroekosistem, antar kelompok pendapatan, antar etnis, atau suku dan antar waktu. Struktur pola dan pengeluaran konsumsi merupakan salah satu indikator tingkat kesejahteraan rumah tangga. Dengan demikian beberapa faktor tersebut dapat mempengaruhi pola konsumsi, namun banyak teori konsumsi menyatakan bahwa pendapatan merupakan salah satu faktor dominan yang mempengaruhi konsumsi.

Pengaruh tingkat pendapatan terhadap tingkat konsumsi mempunyai hubungan yang erat, sebagaimana yang dikatakan Kadariah (2002) pendapatan dan kekayaan merupakan faktor penentu utama dalam konsumsi. Muana (2005) mengatakan bahwa penghasilan seseorang merupakan faktor utama yang menentukan pola konsumsi. Menurut Sukirno (2001) dalam menyusun pola konsumsi, pada umumnya seseorang akan mendahulukan kebutuhan pokok, sedangkan kebutuhan sekunder akan dipenuhi saat tingkat pendapatan meningkat.

Reksoprayitno (2004) mendefinisikan pendapatan (revenue) sebagai total penerimaan yang diperoleh pada periode tertentu. Menurut Mankiw (2012) pendapatan adalah pendapatan yang diterima oleh rumah tangga dan usaha yang bukan perusahaan. Sihotang (2004) mengemukakan bahwa pendapatan dapat diartikan sebagai jumlah penghasilan yang diperoleh dari jasa - jasa kegiatan yang dilakukan yang diserahkan pada suatu waktu terentu atau pendapatan dapat juga diperoleh dari harta kekayaan. Hal ini sesuai dengan yang dikemukakan Mubyarto (2005) bahwa pendapatan adalah hasil berupa uang atau material lainnya.

Dalam penelitian ini pendapatan adalah total penerimaan seseorang berupa uang, dihitung selama satu bulan. Adapun Indikator tingkat pendapatan meliputi: 1.) Golongan pendapatan sangat tinggi adalah jika pendapatan rata rata lebih dari Rp. 3.500.000,00 per bulan; 2.) Golongan pendapatan tinggi adalah jika pendapatan rata - rata antara Rp.2.500.000,00 s/d Rp. 3.500.000,00 per bulan; 3.) Golongan pendapatan sedang adalah jika pendapatan rata - rata antara Rp. 1.500.000 s/d Rp. 2.500.000,00 per bulan; 4.) Golongan pendapatan rendah adalah jika pendapatan rata-rata dibawah dari Rp.1.500.000,00 per bulan. 
Tingkat pendapatan mahasiswa Pascasarjana Universitas Negeri Surabaya bervariasi sesuai dengan pekerjaan dan statusnya, yaitu ada yang Pegawai Negeri Sipil, Pegawai swasta, dan ada yang belum bekerja atau baru lulus Sarjana kemudian langsung melanjutkan ke Pascasarjana. Uang saku diasumsikan sebagai pendapatan yang diterima bagi mahasiswa yang belum bekerja. Pendapatan yang mereka peroleh tesebut digunakan untuk keperluan konsumsi, baik konsumsi kebutuhan pokok seperti biaya pendidikan dan makan, maupun kebutuhan sekunder dan tersier.

Konsumsi merupakan besarnya belanja yang dikeluarkan oleh setiap rumah tangga dalam satu bulan untuk memenuhi kebutuhan hidup, baik makanan maupun bukan makanan. Sebagaimana menurut Samuelson (2000) menjelaskan bahwa konsumsi adalah kegiatan menghabiskan nilai guna barang dan jasa.

Menurut Mankiw (2012) konsumsi adalah pembelanjaan barang dan jasa oleh rumah tangga. Menurut Todaro (2002) konsumsi secara umum diartikan sebagai penggunaan barang-barang dan jasa yang secara langsung akan memenuhi kebutuhan manusia. Konsumsi sebagai pembelanjaan yang dilakukan oleh rumah tangga atas barang dan jasa untuk konsumen akhir atau dibutuhkan oleh seseorang atau masyarakat dengan tujuan untuk memenuhi kebutuhan.

Dalam penelitian ini konsumsi merupakan kegiatan menghabiskan nilai guna barang dan jasa untuk memenuhi kebutuhan hidup, baik kebutuhan pokok, sekunder, maupun tersier. Indikator tingkat konsumsi berdasarkan pengeluaran untuk barang dan jasa yang dikatagorikan sebagai berikut: 1.) Konsumsi pokok dimaksudkan untuk memenuhi kebutuhan primer minimal yang harus dipenuhi untuk dapat hidup; 2.) Konsumsi sekunder, adalah kebutuhan kedua setelah kebutuhan pokok terpenuhi; 3.) Konsumsi Tersier (barang-barang mewah). Konsumsi ini dipenuhi apabila konsumsi kebutuhan pokok dan sekunder telah terpenuhi.

Tingkat konsumsi mahasiswa Pascasarjana Universitas Negeri Surabaya juga bervariasi berhubungan dengan tingkat pendapatan mahasiswa. Berdasarkan pengamatan peneliti rata - rata tingkat konsumsi mahasiswa pascasarjana cukup tinggi, hal tersebut dapat dilihat dari gaya hidup mahasiswa dalam berkonsumsi, misalkan berkaitan dengan fasilitasnya sebagai mahasiswa yaitu membutuhkan buku penunjang, membayar SPP, transportasi baik angkutan umum maupun kendaraan pribadi, kebutuhan akan informasi seperti internet, surat kabar, dan jurnal. Kebutuhan tempat tinggal seperti tempat kos/rumah kontrak bagi mahasiswa yang jauh dari lokasi belajar, kemudian kursus penunjang seperti kursus bahasa Inggris, dan masih banyak lagi pengeluaran konsumsi mahasiswa yang tidak bisa disebutkan satu per satu.

Fenomena yang terjadi sekarang ini, sebagian masyarakat Indonesia mengikuti gaya hidup negara - negara maju. Hal tersebut merupakan indikasi konsumsi dari suatu masyarakat. Saat ini pemilihan konsumsi yang dilakukan bukan hanya untuk memenuhi kebutuhan dasar, tetapi bermakna lain yang lebih riil berkaitan dengan identitas diri yang bersifat prestisius. Akibatnya selain menyebabkan tidak terpenuhinya kebutuhan utama juga akan menyebabkan sikap yang konsumtif (Sumarwan, 2011). 
Studi perbandingan yang dilakukan terhadap pola konsumsi rumah tangga kaya dan miskin di kota Makasar menemukan bahwa terdapat perbedaan yang signifikan antara jumlah konsumsi masing - masing kelompok objek penelitian (Rahma, 2011). Sedangkan Danil (2013) dari hasil penelitiannya menjelaskan bahwa semakin besar tingkat pendapatan, maka semakin tinggi pula tingkat pengeluaran konsumsi.

Selain faktor pendapatan salah satu bagian yang dapat mempengaruhi dalam keputusan untuk melakukan tindakan konsumsi adalah pengetahuan ekonomi. Artinya seseorang yang memiliki kecakapan dibidang ekonomi mampu berperilaku ekonomi yang rasional. Sebagaimana menurut Zamroni (dalam Prasastianta, 2011) menyatakan bahwa secara umum tindakan manusia telah direncanakan sebelumnnya yang dilakukan secara sadar melalui pemikiran yang matang dalam konteks ekonomi, manusia senantiasa mendasari tindakannya untuk mencapai efektivitas dan efisien ekonomi.

Melalui pengetahuan yang dimilikinya, manusia sebagai mahluk ekonomi idealnya mengetahui fakta dan secara logis membandingkan sejumlah pilihan dalam kaitannya dengan biaya dan nilai yang diterimanya untuk memperoleh kepuasan maksimal. Sebagai mahluk ekonomi manusia juga dipandang sebagai individu yang melakukan keputusan secara rasional, salah satu keputusan rasional tersebut adalah tindakan ekonomi sebagai konsumen. Dengan pengetahuan yang dimilikinya seseorang berusaha memenuhi kebutuhan konsumsinya untuk mencapai kepuasan yang tampak dari perilaku sebagai konsumen.

Rendahnya pengetahuan ekonomi akan berdampak pada sikap konsumtif pada masyarakat. Indikasi lain rendahnya pengetahuan ekonomi adalah banyak kasus dan korban penipuan berbalut investasi. Fenomena lainnya adalah rendahnya motivasi masyarakat Indonesia untuk menabung dan kebiasaan belanja yang berlebihan sehingga sulit untuk menjadi konsumen yang cerdas. Dengan menjadi konsumen yang takluk pada hasrat untuk berbelanja secara berlebihan hanya akan menjadikan siklus hidup menjadi semakin jauh dari pencapaian yang diharapkan (Sina, 2012).

Pengetahuan ekonomi merupakan kemampuan untuk mengerti tentang konsep - konsep ilmu ekonomi, yaitu tentang tindakan manusia untuk memenuhi kebutuhan hidupnya yang banyak, bervariasi dan berkembang dengan sumber daya yang ada melalui pilihan-pilihan kegiatan produksi, konsumsi, dan distribusi. Adapun Indikator pengetahuan ekonomi meliputi: 1.) Pengetahuan tentang prinsip ekonomi; 2.) Pengetahuan tentang Motif Ekonomi; 3.) Pengetahuan tentang Tindakan Ekonomi; 4.) Pengetahuan tentang kebutuhan berdasar intensitasnya; 5.) Pengetahuan tentang Hukum Ekonomi.

Pengetahuan ekonomi mahasiswa pascasarjana juga bervariasi. Bagi mahasiswa yang khususnya menempuh ilmu pengetahuan ekonomi atau mahasiswa pendidikan ekonomi tentu memiliki pengetahuan ekonomi yang mumpuni, sedangkan bagi mahasiswa selain prodi ekonomi seperti, mahasiswa pendidikan dasar, IPS, PLB, pendidikan sains dan pendidikan matematika, tentunya pengetahuan ekonomi yang dimiliki hanya sebatas pengetahuan ekonomi secara umum atau pengetahuan ekonomi dasar. Sebagian besar mahasiswa pascasarjana Universitas Negeri Surabaya berprofesi sebagai 
pendidik, selayaknya seorang pendidik memberikan teladan yang baik bagi anak didik khususnya dan masyarakat secara umum dalam bertindak, termasuk dalam melakukan tindakan konsumsi.

Perilaku konsumsi ditentukan oleh tingkat pengetahuan tentang ekonomi, sehingga pengetahuan ekonomi yang dimiliki masyarakat menjadi hal penting. Pengetahuan ekonomi dalam perekonomian suatu negara menjadi penting, karena dengan pengetahuan ekonomi berarti menunjukkan masyarakat suatu negara merupakan konsumen (atau produsen) yang cerdas, sehingga akan mendorong terhadap pertumbuhan produksi dalam negeri yang pada gilirannya akan mendorong terhadap pertumbuhan ekonomi.

Penelitian yang menunjukan pentingnya memiliki pengetahuan ekonomi, yaitu Prasastianta (2001) hasil penelitiannya menunjukkan bahwa pengetahuan ekonomi yang dimiliki siswa mempengaruhi perilaku ekonomi yang rasioanal. Artinya seseorang yang memiliki pengetahuan ekonomi yang baik, dalam melakukan tindakan ekonomi akan bersikap rasional sehingga menjadi konsumen yang cerdas atau tidak konsumsif. Selanjutnya menjadi konsumen yang cerdas maka dapat mengendalikan tingkat konsumsi sesuai dengan tingkat pendapatannya.

Hal ini yang melatarbelakangi penulis untuk meneliti lebih lanjut mengenai "Pengaruh Tingkat Pendapatan, dan Pengetahuan Ekonomi Terhadap Tingkat Konsumsi Pada Mahasiswa Pascasarjana Universitas Negeri Surabaya".

\section{METODE PENELITIAN}

Pendekatan yang digunakan dalam penelitian ini adalah pendekatan kuantitatif. Variabel dalam penelitian ini adalah tingkat pendapatan $\left(\mathrm{X}_{1}\right)$, dan pengetahuan ekonomi $\left(\mathrm{X}_{2}\right)$ sebagai variabel bebas, dan tingkat konsumsi (Y) sebagai variabel terikat. Indikator variabel dijelaskan sebagai berikut:

Tabel 1. Variabel dan Indikator Penelitian

\begin{tabular}{|c|c|}
\hline Variabel & Indikator \\
\hline $\begin{array}{l}\text { Tingkat } \\
\text { Pendapatan }\left(\mathrm{X}_{1}\right) \\
(\mathrm{BPS}, 2013)\end{array}$ & $\begin{array}{ll}\text { 1. } & \text { Sangat tinggi > Rp. } 3.500 .000,00 \\
\text { 2. } & \text { Tinggi Rp.2.500.000,00 s/d Rp. } 3.500 .000,00 \\
\text { 3. } & \text { Sedang Rp. } 1.500 .000 \mathrm{~s} / \mathrm{d} \text { Rp. } 2.500 .000,00 \\
\text { 4. } & \text { Rendah < Rp. } 1.500 .000,00\end{array}$ \\
\hline $\begin{array}{l}\text { Pengetahuan } \\
\text { Ekonomi }\left(X_{2}\right) \\
\text { (McEachern, } \\
\text { 2001) }\end{array}$ & $\begin{array}{l}\text { 1. Pengetahuan tentang prinsip ekonomi } \\
\text { 2. Pengetahuan tentang motif ekonomi } \\
\text { 3. Pengetahuan tentang tindakan ekonomi } \\
\text { 4. Pengetahuan tentang kebutuhan } \\
\text { intensitasnya } \\
\text { 5. Pengetahuan tentang hukum ekonomi }\end{array}$ \\
\hline $\begin{array}{l}\text { Tingkat } \\
\text { Konsumsi (Y) } \\
\text { Samuelson } \\
(2000), \quad \text { Todaro } \\
(2002)\end{array}$ & $\begin{array}{l}\text { 1. Konsumsi barang dan jasa untuk kebutuhan pokok } \\
\text { 2. Konsumsi barang dan jasa untuk kebutuhan sekunder } \\
\text { 3. Konsumsi barang dan jasa untuk kebutuhan tersier }\end{array}$ \\
\hline
\end{tabular}

Sumber: Data diolah, (2015) 
Populasi dalam penelitian ini adalah mahasiswa Program Pascasarjana Universitas Negeri Surabaya, Sedangkan sampel penelitian ditentukan dengan rumus Slovin dan diperoleh ukuran sampel sebesar 237 responden, dengan menggunakan teknik sampling propotional random sampling.

Teknik pengumpulan data yang digunakan dalam penelitian ini meliputi angket, dan dokumentasi. Angket yang digunakan untuk memperoleh informasi tentang tingkat pendapatan, pengetahuan ekonomi, dan tingkat konsumsi. Metode analisis data yang digunakan dalam penelitian ini adalah analisis deskriptif dan regresi berganda. Analisis deskriptif digunakan untuk mengetahui variabel tingkat pendapatan, pengetahuan ekonomi, dan tingkat konsumsi responden. Sedangkan analisis regresi linier berganda digunakan untuk mengetahui besarnya hubungan antara variabel bebas dengan variabel terikat baik secara parsial maupun secara simultan. Persamaan yang digunakan adalah:

Keterangan:

$$
Y=\alpha+\beta_{1} X_{1}+\beta_{2} X_{2}+e_{i}
$$

$\mathrm{Y}=$ Variabel terikat (tingkat konsumsi)

$\mathrm{X}_{1}=$ Variabel bebas (tingkat pendapatan)

$\mathrm{X}_{2}=$ Variabel bebas (pengetahuan ekonomi)

$\alpha=$ Konstanta

$\beta_{1}=$ koefisien regresi variabel X1

$\beta_{2}=$ koefisien regresi variabel $\mathrm{Y}$

$\mathrm{e}_{\mathrm{i}} \quad=$ Faktor penganggu/error

Uji statistik yang digunakan dalam penelitian ini yaitu uji t dan uji F. Uji $\mathrm{t}$ digunakan untuk mengetahui ada atau tidaknya pengaruh tingkat pendapatan $\left(\mathrm{X}_{1}\right)$, dan pengetahuan ekonomi $\left(\mathrm{X}_{2}\right)$ terhadap tingkat konsumsi $(\mathrm{Y})$ secara parsial. Uji $\mathrm{F}$ digunakan untuk mengetahui ada atau tidaknya pengaruh tingkat pendapatan $\left(\mathrm{X}_{1}\right)$, dan pengetahuan ekonomi $\left(\mathrm{X}_{2}\right)$ secara bersama-sama pada tingkat konsumsi (Y).

\section{HASIL DAN PEMBAHASAN}

Bedasarkan hasil distribusi frekuensi data penelitian, diperoleh hasil yang menunjukkan bahwa tingkat pendapatan dengan nilai rata-rata tertinggi yaitu pada tingkat pendapatan katagori sedang (Rp.1.500.000,00 s/d Rp. $2.500 .000,00)$ yaitu sebanyak 88 responden $(37,13 \%)$, sedangkan rata-rata terendah pada tingkat pendapatan katagori sangat tinggi $(\geq \mathrm{Rp}$. 3.500.000,00) yaitu sebanyak 28 responden $(11,81 \%)$, dan untuk tingkat pendapatan katagori rendah $(\leq$ Rp.1.500.000,00) sebanyak 68 responden $(28,69 \%)$, dan pada tingkat pendapatan katagori tinggi (Rp. 2.500.000,00 s/d Rp. 3.500.000,00) sebanyak 53 responden $(22,36 \%)$. Hasil nilai rata-rata tingkat pendapatan sebesar 2,17, hal ini menunjukkan bahwa rata-rata tingkat pendapatan responden termasuk dalam katagori tingkat pendapatan sedang.

Berdasarkan hasil distribusi frekuensi data penelitian, diperoleh hasil yang menunjukkan bahwa pengetahuan ekonomi pada indikator ke-1 (Pengetahuan tentang prinsip ekonomi) merupakan tanggapan responden dengan nilai rata-rata tertinggi yaitu sebesar 3,14 termasuk dalam katagori 
tinggi, sedangkan nilai terendah terdapat pada indikator ke-2 (pengetahuan tentang motif ekonomi) dengan nilai rata-rata sebesar 2,96 termasuk katagori tinggi. Pada indikator-3 (pengetahuan tentang tindakan ekonomi) nilai rata-rata sebesar 2,99, hal ini menunjukkan bahwa pengetahuan responden tentang tindakan ekonomi termasuk katagori tinggi. Pada indikator-4 (pengetahuan tentang kebutuhan berdasarkan intensitasnya) nilai rata-rata sebesar 3,08, hal ini menunjukkan bahwa pengetahuan responden tentang kebutuhan berdasarkan intensitasnya termasuk katagori tinggi. Pada indikator ke-5 (pengetahuan tentang hukum ekonomi) rata-rata nilai sebesar 3,07, hal ini menunjukkan bahwa responden memiliki pengetahuan tentang hukum ekonomi termasuk katagori tinggi.

Berdasarkan hasil distribusi frekuensi data penelitian, diperoleh hasil yang menunjukkan bahwa tingkat konsumsi pada indikator ke-1 (Konsumsi Primer) merupakan tanggapan responden dengan nilai rata-rata tertinggi yaitu sebesar 2,3 termasuk dalam katagori Sedang, sedangkan nilai terendah terdapat pada indikator ke-3 (Konsumsi Tersier) dengan nilai rata-rata sebesar 1,69 termasuk katagori rendah. Pada indikator ke-2 (konsumsi sekunder) nilai ratarata sebesar 1,91, hal ini menunjukkan bahwa tingkat konsumsi responden untuk kebutuhan sekunder termasuk katagori sedang.

Model regresi yang diperoleh berdasarkan hasil penelitian dapat dituliskan dalam bentuk persamaan regresi sebagai berikut:

$$
Y=30,006+9,501 X_{1}-0,347 X_{2}+e_{i}
$$

Berdasarkan persamaan regresi tersebut dapat dijelaskan sebagai berikut: 1.) Konstanta (a) sebesar 30,006 menunjukkan bahwa jika variabel $X_{1}$ (tingkat pendapatan) dan variabel $\mathrm{X}_{2}$ (pengetahuan ekonomi) bernilai 0 , maka Tingkat konsumsi bernilai 30,006 satuan; 2.) Koefisien regresi variabel $\mathrm{X}_{1}$ (tingkat pendapatan) sebesar 9,501 menunjukkan bahwa setiap perubahan variabel $\mathrm{X}_{1}$ akan berpengaruh positif terhadap tingkat konsumsi sebesar 9,501 satuan. Nilai koefisien regresi positif menunjukkan bahwa terjadi pengaruh yang searah antara variabel tingkat pendapatan dan tingkat konsumsi, artinya jika terjadi kenaikan pada variabel tingkat pendapatan maka tingkat konsumsi juga akan naik begitu juga sebaliknya terjadi penurunan variabel tingkat konsumsi jika tingkat pendapatan turun dengan asumsi variabel pengetahuan ekonomi bernilai konstan atau tetap; 3.) Koefisien regresi variabel $\mathrm{X}_{2}$ (pengetahuan ekonomi) sebesar -0,347 menunjukkan bahwa setiap perubahan variabel pengetahuan ekonomi akan berpengaruh negatif terhadap tingkat konsumsi sebesar 0,347 satuan. Nilai koefisien regresi negatif menunjukkan bahwa terjadi pengaruh yang saling berkebalikan antara variabel pengetahuan ekonomi dan tingkat konsumsi, artinya jika terjadi penurunan variabel tingkat konsumsi jika variabel pengetahuan ekonomi naik begitu juga sebaliknya terjadi kenaikan varibel tingkat konsumsi jika variabel pengetahuan ekonomi turun dengan asumsi variabel tingkat pendapatan tidak terjadi perubahan atau konstan.

Pengujian variabel tingkat pendapatan dan pengetahuan ekonomi terhadap tingkat konsumsi secara simultan berpengaruh signifikan terhadap 
tingkat konsumsi. Hasil uji $\mathrm{F}$ berdasarkan uji ANOVA atau uji statistik $\mathrm{F}$ sebagai berikut:

Tabel 2. Hasil Uji F

\begin{tabular}{|ll|r|r|r|r|r|}
\hline Model & & Sum of Squares & df & Mean Square & \multicolumn{1}{|c|}{ F } & Sig. \\
\hline 1 & Regression & 19616.488 & 2 & 9808.244 & 618.841 & $.000^{\mathrm{b}}$ \\
& Residual & 3708.752 & 234 & 15.849 & & \\
& Total & 23325.241 & 236 & & & \\
\hline
\end{tabular}

Sumber: Data diolah, (2015)

Berdasarkan tabel 2 diatas, hasil perhitungan menunjukkan bahwa nilai F hitung yaitu sebesar 618,841 dengan nilai signifikansi 0,000 lebih kecil dari tingkat signifikansi $\alpha=0.05$, sehingga dapat disimpulkan bahwa variabel tingkat pendapatan $\left(\mathrm{X}_{1}\right)$ dan pengetahuan ekonomi $\left(\mathrm{X}_{2}\right)$ secara simultan (bersama) mempunyai pengaruh nyata terhadap tingkat konsumsi (Y).

Nilai koefisien determinasi (adjusted $R$ Square) yaitu sebesar 0,840, ini menunjukkan bahwa besarnya kontribusi antara variabel bebas yaitu tingkat pendapatan $\left(\mathrm{X}_{1}\right)$ dan pengetahuan ekonomi $\left(\mathrm{X}_{2}\right)$ secara simultan menjelaskan perubahan variasi dari variabel terikat Tingkat konsumsi (Y) sebesar 84\% sedangkan sisanya sebesar $16 \%$ dijelaskan oleh variabel lain.

Nilai t-hitung diketahui sebagai berikut:

Tabel 3. Hasil Uji t

\begin{tabular}{|c|c|c|c|c|c|c|}
\hline \multicolumn{7}{|c|}{ Coefficients $^{\mathrm{a}}$} \\
\hline & & \multicolumn{2}{|c|}{$\begin{array}{l}\text { Unstandardized } \\
\text { Coefficients }\end{array}$} & \multirow{2}{*}{$\begin{array}{c}\begin{array}{l}\text { Standardized } \\
\text { Coefficients }\end{array} \\
\text { Beta }\end{array}$} & \multirow[b]{2}{*}{$\mathrm{t}$} & \multirow[b]{2}{*}{ Sig. } \\
\hline \multicolumn{2}{|c|}{ Model } & B & Std. Error & & & \\
\hline \multirow[t]{3}{*}{1} & (Constant) & 30.006 & 3.749 & & 8.004 & .000 \\
\hline & $\begin{array}{l}\text { PENGETAHUAN EKONOMI } \\
\left(\mathrm{X}_{2}\right)\end{array}$ & -.347 & .063 & -.148 & -5.549 & .000 \\
\hline & $\begin{array}{l}\text { TINGKAT PENDAPATAN } \\
\left(\mathrm{X}_{1}\right)\end{array}$ & 9.501 & .270 & .935 & 35.149 & .000 \\
\hline
\end{tabular}

Sumber: Data diolah, (2015)

Berdasarkan tabel 3 di atas dijelaskan bahwa: 1.) Hasil perhitungan variabel tingkat pendapatan menunjukkan nilai sebesar 35,149 dengan nilai signifikansi sebesar $0,00<$ taraf signifikansi $\alpha=0,05$, sehingga dapat disimpulkan bahwa Tingkat Pendapatan $\left(\mathrm{X}_{1}\right)$ secara parsial berpengaruh signifikan terhadap Tingkat konsumsi; 2.) Hasil perhitungan variabel pengetahuan ekonomi menunjukkan nilai sebesar -5,549 dengan nilai signifikansi sebesar $0,00<$ taraf signifikansi $\alpha=0,05$, sehingga dapat disimpulkan bahwa Pengetahuan Ekonomi $\left(\mathrm{X}_{2}\right)$ berpengaruh signifikan terhadap Tingkat konsumsi.

Berdasarkan pengujian dengan analisis regresi linier berganda variabel tingkat pendapatan $\left(\mathrm{X}_{1}\right)$, dan pengetahuan ekonomi $\left(\mathrm{X}_{2}\right)$ secara bersama-sama mempunyai pengaruh yang signifikan terhadap tingkat konsumsi (Y) pada Mahasiswa Program Pascasarjana Universitas Negeri Surabaya. Hal ini menunjukkan bahwa jika seseorang memiliki tingkat pendapatan yang tinggi maka tingkat konsumsinya juga menjadi tinggi, sedangkan jika seseorang 
memiliki pengetahuan ekonomi yang tinggi maka tingkat konsumsinya menjadi rendah, dengan arti tingkat konsumsinya lebih terkontrol atau bisa mengendalikan sesuai kebutuhan.

Hasil penelitian ini mendukung hasil penelitian Benjamin, dkk (2011) yang menyatakan bahwa peningkatan total pendapatan akan menyebabkan peningkatan yang sesuai pada masing-masing kelompok pengeluaran. Penelitian ini juga mendukung hasil penelitian Tapsin dan Hepsag (2014) dengan hasil menunjukkan bukti yang sesuai dengan fungsi konsumsi Keynesian, bahwa terdapat hubungan positif antara pendapatan dan konsumsi.

Hasil penelitian ini tidak mendukung penelitian yang dilakukan oleh Nwabueze (2009) hasil penelitian melaporkan bahwa tidak ada bukti atau dampak yang signifikan dari PDB (pendapatan) pada pengeluaran konsumsi di Nigeria.

Berdasarkan hasil penelitian diketahui bahwa pengetahuan ekonomi berpengaruh negatif dan signifikan terhadap tingkat konsumsi mahasiswa. Penelitian ini mendukung penelitian yang dilakukan oleh Erni (2013) yang menyatakan bahwa terdapat pengaruh antara pembelajaran ekonomi terhadap perilaku konsumsi.

Tingkat pendapatan secara simultan berpengaruh terhadap tingkat konsumsi, hal ini didukung oleh temuan bahwa rata-rata tingkat pendapatan mahasiswa termasuk dalam katagori sedang yaitu antara Rp.1.500.000,- sampai dengan Rp.2.500.000,-, diikuti dengan rata-rata tingkat konsumsi mahasiswa juga termasuk dalam katagori sedang. Berdasarkan temuan tingkat konsumsi mahasiwa untuk kebutuhan konsumsi primer merupakan tanggapan mahasiswa dengan nilai rata-rata tertinggi, sedangkan nilai terendah terdapat pada jenis konsumsi tersier yaitu termasuk dalam katagori rendah. Kemudian tingkat konsumsi mahaiswa untuk kebutuhan sekunder termasuk katagori sedang.

Pengetahuan ekonomi secara simultan berpengaruh terhadap tingkat konsumsi mahasiswa. Temuan dilapangan pengetahuan ekonomi yang dimiliki mahasiswa termasuk dalam katagori tinggi. Pengetahuan ekonomi yang dimiliki tersebut dibentuk dari pemahaman mahasiswa tentang konsep dasar ilmu ekonomi yaitu pengetahuan tentang prinsip ekonomi, motif ekonomi, hukum ekonomi, tindakan ekonomi, dan kebutuhan berdasarkan intensitasnya. Pemahaman tersebut akan mempengaruhi pola konsumsinya, sehingga mahasiswa dengan pengetahuan ekonomi yang baik akan melakukan tindakan ekonomi secara rasional.

Berdasarkan analisis data diperoleh hasil yang menunjukkan bahwa tingkat pendapatan berpengaruh positif dan signifikan terhadap tingkat konsumsi mahasiswa Program Pascasarjana Universitas Negeri Surabaya. Semakin tinggi tingkat pendapatan maka tingkat konsumsi menjadi semakin tinggi.

Hasil penelitian ini mendukung penelitian sebelumnya yang telah dilakukan oleh Danil (2013) yang menunjukkan bahwa semakin besar tingkat pendapatan, maka semakin tinggi pula tingkat pengeluaran konsumsi. Begitu juga dengan penelitian yang dilakukan oleh Akerere dan Yousuo (2012), Upadhyay dan Pathania (2013), Benjamin dan Joseph (2011), Thankgod (2014), Mishra (2011), dan Tapsin dan Hepsag (2014) hasil penelitian 
menunjukkan bukti yang sesuai dengan teori konsumsi Keynes, bahwa terdapat hubungan positif antara tingkat pendapatan dan tingkat konsumsi.

Hasil penelitian ini tidak mendukung penelitian yang dilakukan oleh Chioma (2009), menyatakan bahwa pendapatan tidak berpengaruh signifikan terhadap pengeluaran konsumsi di Nigeria.

Penelitian ini sesuai dengan teori Keynes (dalam Raharja dan Manurung, 2008) menyatakan bahwa konsumsi yang dilakukan saat ini tergantung dari pendapatan yang siap dibelanjakan saat ini (disposible income). Dengan demikian semakin besar pendapatan, maka semakin besar pula pengeluaran konsumsi. Hal ini didukung oleh Muana (2005) yang mengatakan bahwa penghasilan seseorang merupakan faktor utama yang menentukan pola konsumsi.Pengaruh tingkat pendapatan terhadap tingkat konsumsi mempunyai hubungan yang erat sebagaimana yang dikatakan Kadariah (2002) pendapatan dan kekayaan merupakan faktor penentu utama dalam konsumsi.

Pada penelitian ini tingkat pendapatan berpengaruh positif terhadap tingkat konsumsi. Temuan dalam penelitian ini pada variabel tingkat pendapatan menunjukkan bahwa rata-rata tingkat pendapatan responden termasuk dalam katagori sedang yaitu antara Rp.1.500.000,00 sampai dengan Rp.2.500.000,00., dengan diikuti rata-rata tingkat konsumsi responden juga termasuk dalam katagori sedang.

Tingkat konsumsi pada tiap - tiap responden berbeda sesuai dengan tingkat pendapatannya Bagi mahasiswa yang berpendapatan pada tingkat pendapatan katagori rendah (kurang dari Rp.1.500.000,00), rata - rata pendapatannya digunakan untuk pengeluaran konsumsi primer, seperti kebutuhan untuk makan, tempat tinggal, pendidikan, transportasi, dan pakaian. Sedangkan untuk kebutuhan sekunder dan tersiernya rendah.

Bagi mahasiswa yang berpendapatan pada tingkat pendapatan katagori sedang (Rp.1.500.000,00 sampai dengan Rp.2.500.000,00), sebagian besar pendapatannya digunakan untuk kebutuhan pokok, selanjutnya pemenuhan kebutuhan sekunder ditingkatkan, seperti kubutuhan untuk kesehatan, pulsa, kebutuhan rumah tangga, dan peralatan elektronik.

Bagi mahasiswa yang berpendapatan pada tingkat pendapatan katagori tinggi (Rp.2.500.000,00 sampai dengan Rp.3.500.000,00), pengeluaran untuk kebutuhan pokok juga tinggi, disusul pengeluaran konsumsi untuk kebutuhan sekunder yang tinggi, selanjutnya mulai ada peningkatan pada pengeluaran untuk kebutuhan tersier seperti pengeluaran untuk perhiasan, aksesoris, hiburan, kendaraan, dan asuransi serta pajak.

Bagi mahasiswa yang berpendaptan pada tingkat pendapatan katagori sangat tinggi (lebih dari Rp.3.500.000,00), tingkat konsumsinya pun mengikuti katagori sangat tinggi, namun tidak semua pendapatannya dihabiskan untuk pengeluaran konsumsi.

Sebagaimana pendapat Sukirno (2001) pada umumnya seseorang dalam menyusun pola konsumsi akan mendahulukan kebutuhan pokok, sedangkan kebutuhan sekunder akan dipenuhi saat tingkat pendapatannya meningkat. Temuan menunjukkan bahwa responden yang mempunyai pendapatan rendah mengeluarkan sebagian besar pendapatannya untuk pangan. Sebaliknya, ketika pendapatannya tinggi pengeluaran untuk pangan hanya sebagian kecil saja dari total pengeluaran. Kondisi ini menunjukkan adanya hubungan yang terbalik 
antara persentase kenaikan pendapatan dengan persentase pengeluaran untuk pangan. Keadaan ini dikenal dengan Hukum Engel (Engel's Law). Kaitan antara tingkat pendapatan dengan pola konsumsi sebagaimana hukum Engel menerangkan bahwa pendapatan disposable yang berubah-ubah pada berbagai tingkat pendapatan, dengan naiknya tingkat pendapatan maka persentase yang digunakan untuk sandang dan pelaksanaan rumah tangga adalah cenderung konstan. Sementara persentase yang digunakan untuk pendidikan, kesehatan dan rekreasi semakin bertambah.

Berdasarkan analisis data diperoleh hasil yang menunjukkan bahwa pengetahuan ekonomi berpengaruh negatif dan signifikan terhadap tingkat konsumsi mahasiswa Program Pascasarjana Universitas Negeri Surabaya. Dengan demikian dapat diartikan bahwa semakin tinggi pengetahuan ekonomi mahasiswa maka semakin rendah tingkat konsumsi mahasiswa, begitu pun sebaliknya semakin rendah pengetahuan ekonomi yang dimiliki mahasiswa maka tingkat konsumsi mahasiswa semakin tinggi.

Penelitian ini mendukung penelitian sebelumnya yang dilakukan oleh Prasastianta (2001) hasil penelitiannya menunjukkan bahwa pengetahuan ekonomi yang dimiliki siswa mempengaruhi perilaku ekonomi yang rasioanal. Artinya seseorang yang memiliki pengetahuan ekonomi yang baik, dalam melakukan tindakan ekonomi akan bersikap rasional sehingga menjadi konsumen yang cerdas atau tidak konsumsif.

Hasil penelitian ini juga mendukung penelitian yang dilakukan oleh Aisyah (2011) yang melaporkan bahwa rendahnya pengetahuan ekonomi yang dimiliki mahasiswa menyebabkan tingginya tingkat konsumsi.

Pengetahuan ekonomi berpengaruh terhadap tingkat konsumsi, hal ini didukung oleh temuan bahwa rata-rata pengetahuan ekonomi mahasiswa termasuk dalam katagori tinggi, indikator ke-1 yaitu pengetahuan tentang prinsip ekonomi merupakan tanggapan responden dengan nilai rata-rata tertinggi yaitu sebesar 3,14 termasuk dalam katagori tinggi, sedangkan nilai terendah terdapat pada indikator ke-2 yaitu pengetahuan tentang motif ekonomi dengan nilai rata-rata sebesar 2,96 termasuk katagori tinggi. Pada indikator pengetahuan tentang tindakan ekonomi nilai rata-rata sebesar 2,99, hal ini menunjukkan bahwa pengetahuan responden tentang tindakan ekonomi termasuk katagori tinggi. Selanjutnya pada indikator pengetahuan tentang kebutuhan berdasarkan intensitasnya, nilai rata-rata sebesar 3,08, hal ini menunjukkan bahwa pengetahuan responden tentang kebutuhan berdasarkan intensitasnya termasuk katagori tinggi. Kemudian pada indikator pengetahuan tentang hukum ekonomi, nilai rata-rata indikator pengetahuan tentang hukum ekonomi sebesar 3,07, hal ini menunjukkan bahwa responden memiliki pengetahuan tentang hukum ekonomi termasuk katagori tinggi.

Pemahaman tersebut akan mempengaruhi pola konsumsi, sehingga mahasiswa dengan pengetahuan ekonomi yang baik akan melakukan tindakan ekonomi secara rasional. Hal ini sesuai dengan pendapat Zamroni (dalam Prasastianta, 2001) bahwa secara umum tindakan manusia telah direncanakan sebelumnnya yang dilakukan secara sadar melalui pemikiran yang matang dalam konteks ekonomi, manusia senantiasa mendasari tindakannya untuk mencapai efektivitas dan efisien ekonomi. Artinya seseorang yang memiliki kecakapan dibidang ekonomi mampu berperilaku ekonomi yang rasional, 
dengan demikian seseorang yang memiliki pengetahuan ekonomi yang baik maka akan bisa mengendalikan tingkat konsumsinya.

\section{SIMPULAN}

Berdasarkan penelitian yang telah dilakukan, beberapa kesimpulan yang dapat diambil sebagai berikut: 1.) Tingkat pendapatan berpengaruh positif dan signifikan terhadap tingkat konsumsi mahasiswa Pascasarjana Universitas Negeri Surabaya. Artinya semakin tinggi tingkat pendapatan maka semakin tinggi pula tingkat konsumsi mahasiswa dengan asumsi bahwa variabel pengetahuan ekonomi adalah konstan; 2.) Pengetahuan ekonomi berpengaruh negatif dan signifikan terhadap tingkat konsumsi mahasiswa Pascasarjana Universitas Negeri Surabaya. Artinya semakin tinggi pengetahuan ekonomi yang dimiliki mahasiswa maka tingkat konsumsinya semakin rendah; 3.) Tingkat pendapatan dan pengetahuan ekonomi secara bersama berpengaruh signifikan terhadap tingkat konsumsi mahasiswa Pascasarjana Universitas Negeri Surabaya. Hal ini berarti tingkat pendapatan dan pengetahuan ekonomi secara simultan memiliki pengaruh nyata terhadap tingkat konsumsi mahasiswa Pascasarjana Universitas Negeri Surabaya.

\section{DAFTAR RUJUKAN}

Aisyah, I. 2011. Faktor-faktor yang Mempengaruhi Preferensi Konsumen. Jurnal Pendidikan Ekonomi \& Koperasi UPI, Vol. 6, No. 1, (PP: 168-188).

Benjamin, C., \& Joseph, C. 2011. Disaggregated Engel Function Analysis of Income and Expenditure among Nigerian Small Scale Farmers. "International Conference on Agricultural and Animal Science", Singapore: IPCBEE. 71-75.

BPS. 2013. Provinsi Jawa Timur Dalam Angka.

Chioma, N. J. 2009. Causal Relationship between Gross Domestic Product and Personal Consumption Expenditure of Nigeria. African Journal of Mathematics and Computer Science Research. Vol. 2, No. 8, (PP: 179183).

Danil, M. 2013. Pengaruh Pendapatan Terhadap Tingkat Konsumsi Pada Pegawai Negeri Sipil di Kantor Bupati Kabupaten Birenuen. Jurnal Ekonomika Universitas Almuslim Bireuen, Vol. 4, No. 7, (PP: 33-41).

Erni, R. 2013. Pengaruh Pembelajaran Ekonomi dan Status Sosial Ekonomi Terhadap Perilaku Konsumsi. Pontianak: Untan.

Kadariah. 2002. Analisis Pendapatan Nasional. Jakarta: Bina Aksara.

Mankiw, G. 2012. Teori Makro Ekonomi. Jakarta: PT Gramedia Pustaka Utama.

McEachern, W. A. 2001. Ekonomi Mikro. Jakarta: Salemba Empat.

Mishra, P. K. 2011. Dynamics of The Relationship Between Real Consumption Expenditure and Economic Growth in India. Indian Journal of Economics and Business, Vol. 10, No. 4, (PP: 553-563). 
Muana, N. 2005. Makro Ekonomi, Teori, Masalah dan Kebijakan (2nd ed.). Jakarta: Raja Grafindo Persada.

Mubyarto. 2005. Pengantar Ekonomi Pertanian. Jakarta: LP3ES.

Nwabueze, J. C. 2009. Causal relationship between gross domestic and personal consumption expenditure of Nigeria. African Journal of Mathematics and Computer Science Research, Vol. 2, No. 1, (PP: 179-183).

Prasastianta, D. E. 2011. Pengaruh Minat Pada Pelajaran Ekonomi, Status Sosial Ekonomi Orang Tua, Pengetahuan Ekonomi dan Rasionalitas Ekonomi Terhadap Perilaku Ekonomi. (Tesis, Magister Pendidikan Ekonomi tidak dipublikasikan). Universitas Negeri Malang.

Rachman, H. 2001. Kajian Pola Konsumsi dan Permintaan Pangan Masyarakat Berpendapatan Rendah Jawa Tengah dan Nusa Tenggara Barat. Jurnal Agro Ekonomi, Vol. 15, No. 2, (PP: 36-53).

Rahma, A. 2011. Studi Perbandingan Pola Konsumsi Pangan dan Non Pangan Rumah Tangga Kaya dan Miskin di Kota Makasar. Makasar: Universitas Hasanuddin.

Reksoprayitno. 2004. Sistem Ekonomi dan Demokrasi Ekonomi. Jakarta: Bina Grafika.

Samuelson, R. 2000. Makro Ekonomi (XIV ed.). Jakarta: Erlangga.

Sihotang, M. 2004. Konsumsi Masyarakat dan Faktor - faktor yang Mempengaruhi Konsumsi. Jakarta: Pustaka Binaan Grafindo.

Sina, P. G. 2012. Analisis Literasi Ekonomi. Jurnal Economica, Vol. 8, No. 2, (PP: 135-143).

Sukirno, S. 2001. Ekonomi Mikro (Edisi Ketiga). Yogyakarta: LPFE UGM.

Sumarwan, U. 2011. Perilaku Konsumen teori dan penerapannya dalam pemasaran. Bogor: Ghalia Indonesia.

Tapsin, G., \& Hepsag, A. 2014. An Analysis of Household Consumption Expenditures in Ea-18. European Scientific Journal, Vol. 10, No. 16, (PP: 1-12).

Thankgod, A. O. 2014. Private Consumption Expenditure Function in Nigeria: Evidence from the Keynes' Absolute Income Hypothesis. International Journal of Research in Social Science, Vol. 4, No. 3, (PP: 53-58).

Todaro. 2002. Ekonomi dalam Pandangan Modern (Terjemahan). Jakarta: Bina Aksara.

Upadhyay, H., \& Pathania, R. 2013. Consumer Expenditure Behavior in India: a Case of Rural and Urban Consumer. International Journal of Business and Management Invention, Vol. 2, No. 2, (PP: 68-73). 